\title{
Are firms with different CSR profiles equally innovative? An empirical analysis with survey data
}

\author{
Rachel Bocquet $^{\mathrm{a}}$, Christian Le Bas ${ }^{\mathrm{b}}$, Caroline Mothe ${ }^{\mathrm{c}}$, Nicolas Poussing ${ }^{\mathrm{d}^{*}}$
}

\begin{abstract}
${ }^{\text {a, c }}$ Université de Savoie, IREGE, 4 Chemin de Bellevue, BP 80439, 74944 Annecy le Vieux Cedex, France ${ }^{\mathrm{b}}$ GATE, Lyon St Etienne (Groupe d'Analyse et de Théorie Economique) - CNRS - University of Lyon CNRS UMR 5824, 93 Chemin des mouilles, 69130 Ecully, France

${ }^{\mathrm{d}}$ CEPS/INSTEAD, 3, Avenue de la Fonte, 4364 Esch-sur-Alzette, Luxembourg - CREM, Université Rennes 1, France
\end{abstract}

* Corresponding author. E-mail address: nicolas.poussing@ ceps.lu tel.: (352) 58.58.55.503 


\title{
Are firms with different CSR profiles equally innovative? Empirical analysis with survey data
}

\begin{abstract}
Summary
This paper explores the relationship between corporate social responsibility (CSR) and innovation from a firm strategic perspective. Matching Community Innovation Survey data with specific data collected about the CSR behaviour of Luxembourg firms, the authors identify two types of firms (strategic versus responsive) that differ in the intensity of their CSR adoption. A bivariate probit model, estimated to explain the different types of technological innovations (product and/or process), shows that firms with strategic CSR profiles are more likely to innovate in both products and processes. In contrast, adopting responsive CSR practices significantly alters firms' innovation, such that CSR may create barriers to innovation. These results have implications for theory and offer managerial recommendations for firms designing their innovation strategies.
\end{abstract}

KEYWORDS: Corporate Social Responsibility, Innovation, Product, Process, Strategic Profiles 


\section{Introduction}

Corporate social responsibility (CSR) has received increased attention from managers and researchers in the past decade (e.g. Baden et al., 2009; Banerjee, 2007; Chassagnon, 2011; Fernando, 2010; Harwood et al., 2011; Knox \& Maklan, 2004; Muller, 2006; Perrini, 2005; Weber, 2008). These studies focus on various dimensions (and related measurement criteria) of CSR, such as the determinants of CSR engagement, the specificities of CSR in small and medium-sized enterprises (SMEs), and the link between CSR and firm performance or value creation. Although the business benefits of CSR also have been subject to substantial research (for reviews, see Knox \& Maklan, 2004; Weber, 2008), a significant gap remains "between the goals of the European Commission (which saw CSR as a vital link between innovation and competitiveness on the one hand and social inclusion on the other) and, with a few exceptions, the perceptions of scientific CSR academics" (European Commission, 2011, p. 12). With this research we attempt to address one of the main weaknesses of extant European CSR research and respond to the demand for a better theoretical and empirical understanding of the relationships between CSR and innovation, especially because "Driving innovation (e.g. fuel innovation or packaging innovation)" (European Commission, 2011, p. 28) is one of the main benefits of engaging in CSR. Accordingly, our research reflects the European Commission's (2011) seventh Framework Program's agenda, which set "more ambitious goals ... relating CSR directly to economic growth (and) innovation" (p. 33).

In this effort, we recognise that most CSR literature has tried to identify an effect on financial performance and produced contradictory results. As McWilliams and Siegel (2001) note, this lack of consensus might reflect model specification problems, such as omissions of R\&D spending. Surroca et al. (2010) also demonstrate that intangible resources, including innovation, might be a missing link to explain relationships between CSR and financial performance. Despite recognition of the importance of innovation as a means to understand the impact of CSR, we remain in a "continuing state of emergence" (Lockett et al., 2006, p. 133) as far as theoretical approaches, assumptions, and methods are concerned.

We also find that previous studies focus almost exclusively on a specific aspect of CSR, namely, environmental practices. This perspective derives from the Porter hypothesis, which asserts that well-designed regulations can "trigger innovation that may partially or more than fully offset the costs of complying with them" (Porter \& van der Linde, 1995, p. 98). Various studies test and confirm this predicted positive effect of environmental regulation on firms' innovation (e.g. Jaffe \& Palmer, 1997; Rennings \& Rammer, 2011). More recently, this notion also has extended to CSR in an effort to understand the extent to which practices that go 
beyond the letter of the law might drive innovation (McWilliams \& Siegel, 2001). The relationship among CSR, environmental practices, and innovation can reflect different theoretical perspectives. For example, using supply and demand theory, McWilliams and Siegel (2001) argue that CSR is an investment in product differentiation that sparks both process and product innovations. Applications of the resource-based view of the firm (RBV; Hart, 1995; Surroca et al., 2010) suggest environmental strategies can lead to the development of firm-specific capabilities (including innovation) that can be sources of competitive advantage. Yet Gallego-Alvarez et al. (2011), analysing the bi-directional relationship between CSR and innovation, offer evidence that sustainable practices do not always lead to value creation and innovation, contrary to previous findings (Wagner, 2010).

Still other authors (e.g. Carroll, 1999; Hart, 1995; Wartick \& Cochrane, 1985; Wilson, 1975) attempt finer characterisations of the types of CSR responses that firms adopt, situating them on a continuum between reactive and proactive end-points. Wilson (1975) identifies four generic firm-level approaches (reactive, defensive, accommodative, and proactive); Hart (1995) attempts to link them to innovation, though his analysis remains limited to the environmental elements. Sharma and Vredenburg (1998) extend his theoretical approach by reintroducing the idea of significantly different effects of proactive versus reactive strategies. That is, proactive responsiveness to uncertainties in business and ecological issues appear associated with the emergence of unique organizational capabilities. Another characterisation, provided by Burke and Logsdon (1996), explicitly links innovation to social, environmental, and economic CSR issues. Porter and Kramer $(2006,2011)$ also argue that poor alignment between firms' CSR approaches and business strategies obscures the greatest opportunities for firms, namely, to gain a sustainable competitive advantage and create shared value that also benefits society.

Despite all these theoretical contributions, no empirical tests or cluster analyses describe the direct effect of CSR strategies on innovation; despite various attempts to differentiate strategic CSR profiles, the actual impact of these various profiles on technological innovation remains unclear. According to Wagner (2010, p. 583), “corporate sustainability and [corporate social performance]/CSR are less narrowly defined measures.... Hence, a study using one of [them] contributes by extending earlier analyses whilst building on their conceptual arguments and rigid methodology". We adopt this perspective and attempt to address the research gap pertaining to the complex relationship between innovation and CSR. Specifically we ask, Which CSR practices do firms adopt, and how to they relate to different types of technological innovation (product, process, or both)? Such relationships may be key to 
understanding firms' competitive position, because the impacts of product and process innovations on market shares and profit differ greatly (Fagerberg, 2005). We therefore work to delineate the links between firms' various CSR strategies (proactive or strategic, reactive or responsive) and the different types of innovation (product/process).

Using a merged data set that combines an original CSR Luxembourg firm-level survey with the fifth Community Innovation Survey, we specify CSR firms' profiles and assess their impacts on product and/or process innovations. To characterise the firms' profiles, we adopt a strategic approach to CSR that clearly acknowledges the link between CSR and innovation. With regard to CSR practices, our cluster analysis reveals two CSR firm profiles (clusters): strategic (Cluster 1) and responsive (Cluster 2). We test whether belonging to a CSR cluster is a key determinant of a firm's (type of) innovation. By estimating a bivariate probit model, we also show that firms with strategic CSR profiles are more likely to innovate in both products and processes, whereas adopting responsive CSR practices significantly alters their innovation process, such that CSR even might create barriers to innovation.

The remainder of the paper is organized as follows: Section 2 contains our analytical framework related to CSR practices and their potential link with innovation. In Section 3, we describe the data and sample. Section 4 outlines the cluster analysis; Section 5 presents the results from the estimated bivariate probit model. In the conclusion, we offer both theoretical and managerial implications, as well as describe the main limitations of our study and some avenues for further research.

\section{Literature review: A framework of CSR profiles and innovation}

An understanding of the process by which "companies integrate social and environmental concerns to their business operations and in their interactions with stakeholders on a voluntary basis" (Commission of the European Communities, 2001, p. 6) emerges from strategic management literature, which not only identifies CSR practices but also addresses the link between CSR and innovation. As Lockett et al. (2006) note though, CSR in strategic management literature is far from an established field; in particular, no consensus exists about the impact of CSR on firms' innovation.

In this sense, strategic management literature comprises two main streams. First, studies that link environmental practices to innovation have been extended to the broader concept of CSR. Second, literature in this field has established that types of strategic behaviour, and especially environmental strategies, lead to diverse performance effects. 
However, no studies sit at the intersection of these two streams, which prompts our main research interest: Are firms' CSR profiles (proactive/strategic versus reactive/responsive) linked to different levels of technological innovation performance and different types of innovation (product and/or process)?

\section{Environmental practices, CSR, and innovation}

The impact of CSR, through the adoption of environmental practices, on innovation has been extensively studied. A strategic perspective explicitly incorporates innovation and views it as an endogenous force that drives new resource combinations to sustain competitive advantages. Innovation heralds the introduction of new products and processes that, if embraced by the market, will enhance firms' performance. As firms work to recognise, manage, and reduce environmental impacts, they potentially reap competitive advantages (Hart, 1995; Porter \& van der Linde, 1995; Russo \& Fouts, 1997), captured in the form of enhanced innovation. Nidumolu et al. (2009, p. 57) even state explicitly that CSR and sustainability are "key drivers for innovation".

Using supply and demand theory as a framework, McWilliams and Siegel (2001) show that the adoption of environmental practices, going beyond legal requirements, may promote investments in Research and Development $(\mathrm{R} \& \mathrm{D})$, which in turn can produce both process and product innovations. They also argue that there is a presumption that firms that actively support the stewardship of the environment are more reliable and offer products of higher quality. Other frameworks, such as those based on the RBV of the firm (Hart, 1995), take into account the multi-dimensional character of CSR. For example, Wagner (2010) uses panel data to test empirically the relationship between corporate social performance measured by the Kinder Lydenberg Domini Inc. ${ }^{1}$ index and innovation. That study reveals that CSR, conceptualised as a multi-dimensional appraisal of a firm's responsible performance, leads to innovation and strong social benefits. Using a two-step estimation that corrects for endogeneity, Surroca et al. (2010) demonstrate that intangible resources (including innovation, which they measure as the ratio of $R \& D$ expenses to the total number of firm employees) mediate the bi-directional relationship between CSR and firms' financial performance. This "virtuous circle" appears stronger in growth industries than in non-growth industries. Using a dynamic panel data model to control for unobservable heterogeneity, Gallejo-Alvarez et al. (2011) also analyse this bidirectional relationship but rely on the RBV and suggest a negative effect of CSR on

\footnotetext{
${ }^{1}$ This global sustainability index benchmarks the top companies in all sectors across the Asia-Pacific, Europe, and North America.
} 
innovation. Thus, not all CSR practices seem to create value. In particular, we predict that the type of CSR strategy—reactive or proactive-may have differentiated impacts (McWilliams \& Siegel, 2000; Porter \& Kramer, 2006; Sharma \& Vredenburg, 1998). Moreover, many studies have used narrow measures of innovation (i.e. R\&D) that cannot fully capture innovation efforts (Mairesse \& Mohnen, 2010) or prevent the differentiation of various types of innovation (product/process), despite their potentially varying effects on performance (Bocquet, 2011). The use of such proxies also might help explain the contradictory results proposed by Wagner (2010) versus Gallego-Alvarez et al. (2011).

\section{Strategic CSR behaviour and the missing direct link to innovation}

Strategic management literature reveals that the Porter hypothesis does not always dominate firms' CSR actions in environmental or social areas. Some authors thus try to identify the type of CSR strategy that best favours innovation, mainly by distinguishing between proactive and reactive firms. However, they focus almost exclusively on environmental strategies. Building on Hart's (1995) classification, Buysse and Verbeke (2003) assess the linkages between proactive environmental strategies and stakeholder management with an empirical application to large, polluting firms active in Belgium. Specifically, they use a cluster analysis to classify firms according to their environmental management practices and identify three dominant environmental management strategies: (1) reactive, (2) pollution prevention, and (3) environmental leadership. Many firms in their sample had shifted from a reactive to a pollution prevention strategy, but only a minority (mostly multi-national firm affiliates) had adopted an environmental leadership strategy.

One study links environmental strategic behaviours to organizational capabilities, including innovation. That is, Sharma and Vredenburg (1998) find that firms with a positive environmental strategy develop unique capabilities, such as higher order learning and continuous innovation, which they cite as outcomes of environmental responsiveness. They find that proactive firms seek opportunities and experiment at the business/environment interface. Other evidence also indicates that developing environmentally friendly processes and products requires firms to be more innovative than firms that choose not to pursue such environmental actions (Aragón-Correa \& Sharma, 2003; Dibrell et al., 2011).

However, these studies limit their analyses to environmental aspects, without introducing a general CSR construct to capture effects on innovation. This limit is unsatisfactory, because it ignores a potentially important area demarcating the relationship between CSR and corporate performance (Devinney, 2009). Therefore, we extend these studies 
to CSR as a whole, not just to its environmental aspects, to analyse whether firms with different CSR strategic profiles innovate differently.

\section{Main hypothesis: CSR strategic profiles and types of innovation}

Burke and Logsdon (1996) transpose the CSR strategic approach to assert that engaging in social, societal, and/or environmental actions provides opportunities for value creation. Porter and Kramer's (2006) framework completes this approach by introducing a clear distinction between proactive and reactive strategies and their potential (distinct) effects on innovation. With the exception of Husted and Allen (2007), such frameworks have led to few empirical applications; most investigations of CSR remain conceptual or rely on qualitative case studies (e.g. Jenkins, 2006; Moore et al., 2009; Murillo \& Lozano, 2006; Tencati et al., 2004). These methodologies certainly are well adapted to descriptions of CSR practices, but they cannot reveal the impact of the different types of CSR (proactive and reactive) on innovation. Husted and Allen's (2007) empirical study offers a partial test of Burke and Logdson's model; it cannot not demonstrate how value creation is associated with the positive alignment of all strategic dimensions that characterise proactive strategies (Porter \& Kramer, 2006). Therefore, we aim to complete the strategic CSR framework (Carroll, 1999; McWilliams \& Siegel, 2000; Porter \& Kramer, 2006; Sharma \& Vredenburg, 1998; Wilson, 1975; Wartick \& Cochrane, 1985), beginning with Burke and Logsdon's (1996) framework as a foundation, for two main reasons.

First, their framework can establish a strong link between the strategic CSR profile and innovation in terms of products and processes. It "appears to be useful in understanding value creation via CSR projects" (Gallego-Alvarez et al., 2011, p. 1713), and "value creation is necessarily about innovation" (Husted \& Allen, 2007, p. 597). Value accrues when consumers are willing to pay more for the firm's products and services because of the social issues it defends (product innovation). Value creation also occurs when resources are combined in new ways to increase their efficiency (process innovation). Distinguishing between these two main types of technological innovation is crucial (Rehfeld et al., 2007), in that they have unique effects on market share and profits and clearly induce different levels of economic performance. With respect to their determinants, some factors are common, but others are specific to either product or process innovation (Bocquet, 2011; Cabagnols \& Le Bas, 2002).

Second, we aim to distinguish the effects of two CSR profiles (strategic versus responsive) on innovation. Burke and Logsdon's (1996) framework explicitly introduces the strategic dimension of CSR as a means to understand the extent to which CSR leads to value 
creation. Consistent with strategic management literature, they argue that value creation through CSR, in addition to distinctive capabilities, requires a positive alignment of all strategic dimensions (Burke \& Logsdon, 1996, p. 497), as follows:

- Centrality, or "closeness of fit to the company's mission and objectives";

- Proactivity, defined as the "degree to which the program is planned in anticipation of emerging social trends and in the absence of crisis";

- Voluntarism, which is "the scope for discretionary decision-making and the lack of externally imposed compliance requirements";

- Visibility, or "observable, recognizable credit by internal and/or external stakeholders for the company"; and

- Specificity, indicating the "ability to capture private benefits by the company".

These five dimensions can serve to characterise firms according to their CSR practices, with splits based on high (strategic CSR) versus low (responsive CSR) scores. This empirical strategy is consistent with Porter and Kramer's (2006) identification of two firm profiles that reflect whether the firm considers CSR a response or a strategic lever. This distinction thus indicates the way the firm integrates all strategic CSR dimensions into its strategic vision.

Strategic CSR requires an alignment between CSR and the firm's growth strategy, which then creates a virtuous circle that allows innovation activities to develop. Husted and Allen (2007) omit two key variables (centrality and proactivity) that refer to strategic alignment with the core business and CSR strategy (Porter \& Kramer, 2006), such that their results may underestimate the impact of CSR on value creation. Strategic CSR seemingly should turn the related expense into a measurable potential return (McWilliams \& Siegel, 2001; Wagner, 2010), as well as a unique, distinctive competitive position (e.g. "lower cost, better service"). We capture these effects through process and product innovations, from which perspective strategic CSR, based on a symbiotic relation between society and a firm's competitiveness, offers a main determinant of both product and process innovations. Sharma and Vredenburg (1998) also find that proactive companies perceive competitive benefits emerging from their environmental engagement, and those benefits include innovations in processes and products. Thus, we hypothesise:

Hypothesis 1: The engagement of a firm in strategic CSR has a positive effect on its propensity to innovate (in both products and processes). 
In contrast, responsive CSR corresponds to the most basic level of CSR, that is, "acting as a good corporate citizen, attuned to the evolving social concerns of stakeholders, and mitigating existing or anticipated adverse effects from business activities" (Porter \& Kramer, 2006, p. 85). The implementation of best practices, as characterises responsive CSR, may contribute to continuous improvement, but they are often disconnected from the firm's overall strategy. Although it ensures firm legitimacy, this approach may cause tensions and conflict with an internal logic of efficiency (Fiss \& Zajac, 2006). Such a "decoupling" also could hinder the firm's ability to innovate in processes and/or products. In this sense, responsive practices place additional constraints on the innovation process and might slow its pace (Castiaux, 2009). They can limit the freedom and creativity needed for innovation processes, even creating a vicious circle in that respect. This consideration matches Miles and Snow's (1978) identification of a "reactor" type as a form of "strategic failure," because of the inconsistencies across its strategy, technology, structure, and process. Studying the impact of supply chain pressures on SMEs to engage in CSR, Baden et al. (2009) show that such pressures can be counter-productive in the absence of intrinsic motivations of owner/managers. Imposed practices increase bureaucracy costs and set lower standards than firms would set for themselves. Moreover, Sharma and Vredenburg (1998, p. 735) find that reactive companies "perceived environmental responsiveness as detracting from this objective" of improving the creation of value. Thus:

Hypothesis 2: The engagement of a firm in responsive CSR has a negative effect on its propensity to innovate (in both products and processes).

\section{Methodology}

\section{Data}

To test our main hypothesis, we used data from two surveys conducted by CEPS/INSTEAD (Luxembourg): the fifth Community Innovation Survey (CIS 6) and a survey relative to CSR practices in firms. Both provide information about CSR practices and innovation performance at the firm level.

The Community Innovation Survey (CIS 6) was conducted in each member state. The quality dimensions are based on the standard defined by Eurostat. We used data collected in Luxembourg, by CEPS/INSTEAD on behalf of STATEC with financial support from the European Commission (Eurostat), which includes the following economic sectors as the core 
target population for the CIS 6: manufacturing (NACE ${ }^{2} 15-37$ ); electricity, gas, and water supply (NACE 40-41); wholesale trade (NACE 51); transport, storage, and communication (NACE 60-64); financial intermediation (NACE 65-67); computer and related activities (NACE 72); architectural and engineering activities (NACE 74.2); and technical testing and analysis (NACE 74.3). All the enterprises included in the target population have at least 10 employees. The observation period covered by the survey is 2004-2006, which entails a threeyear period from the start of 2004 to the end of 2006. The reference period for CIS 6 is 2006 . The sample was drawn from the national business register provided by the National Institute of Statistics in Luxembourg (Statec) at the end of 2006. We obtained 568 responses.

The CSR survey was carried out in Luxembourg during the same period but included all economic sectors. Firms with at least 10 employees appeared in the survey. From this population of 3,296 companies, we built a sample of 2,511 firms that employed at least 50 people and then created stratified random sampling for companies with 10-49 employees. The data collection took place by mail, with a questionnaire in French and German (English was available on request). We received 1,144 valid questionnaires, ${ }^{3}$ most of which $(51 \%)$ indicated the firms had adopted CSR for more than two years (37\% for more than five years).

To analyse simultaneously CSR and innovation, we merged the responses obtained from the two surveys. This final sample consists of 266 enterprises that responded to both surveys, which we categorised into three size classes (10-49 employees, 50-249 employees, and 250 or more employees). Considering its relatively small size, we simply break the sample into two economic sectors: industry (mining and quarrying, manufacturing, electricity, and gas and water supply) versus services (wholesale trade, transport, storage and communication, financial intermediation, computer and related activities, architectural and engineering activities, and technical testing and analysis).

To produce valid results for the target population (i.e. result representativeness), we also weighted the survey results to adjust for the merging procedure, sampling design, and unit nonresponse. A calibration, carried out with the SAS macro developed by INSEE in France, or CALMAR (Calibration on Margins), used auxiliary information: the number of firms per sector and the number of employees per sector. Our statistical analyses rely on this weighting.

Our empirical procedure included two steps. First, using the CSR survey, we conducted a non-hierarchical cluster analysis to classify the firms in relation to their CSR practices. Second, we used the sample that we obtained after merging the CIS and CSR surveys. With a bivariate

\footnotetext{
${ }^{2}$ This acronym refers to the statistical classification of economic activities in the European Community.

${ }^{3}$ The descriptive statistics about the population and sample by NACE code and firm size are available on request.
} 
probit model, we then considered the link between CSR profiles and technological innovation (product and/or process).

\section{A Cluster analysis for CSR profiles (Step 1)}

We first classified firms that had responded to the CSR survey according to their CSR practices.

\section{Variables and measures}

Our survey data describe CSR practices according to the five dimensions identified by Burke and Logsdon (1996):

- Centrality. This dimension, which Husted and Allen (2007) excluded from their empirical model, consists of two binary variables: ${ }^{4}$ the existence of documents that describe values and motivations in terms of social issues (DOC) and whether the firm describes its CSR practices in its annual report, in a dedicated report, or on its website (SUP). As Porter and Kramer $(2006,2011)$ show, creating value through CSR requires not just additional capabilities but also a fit among CSR values, goals and practices, and the core business strategy. Firms that formalise their CSR strategy likely integrate CSR into their corporate business, to gain reputational advantages.

- Proactivity. Also excluded from Husted and Allen's (2007) test, we measure this dimension with two binary variables: the existence of CSR action planning (PLAN) and the existence of an agenda (AGENDA). These variables capture the firm's ability to gain a first-mover advantage by anticipating changes in social issues.

- Voluntarism. This binary variable assesses whether the firm has identified stakeholders for its CSR actions (STAKE). Similar to Husted and Allen (2007), we use this consideration to determine if voluntary actions are undertaken freely or under pressure, to fit the firm's strategy.

- Visibility. We use another binary variable for this dimension to assess whether the firm has an external or we use another internal communication plan (COM). Unlike Husted and Allen (2007) but similar to Buysse and Verbeke (2003), we focus on the means of communication (internal and external) that firms use to increase their visibility, rather than on the purpose of the communication. Thus we avoid any confusion with the “specificity" dimension and better align with Burke and Logsdon's (1996) definition.

\footnotetext{
${ }^{4}$ All dummies for the variables in this cluster analysis take values of $1=$ "no" or $2=$ "yes".
} 
- Specificity. The three variables for this dimension use four-item Likert scales, ranging from 1 ("no perceived benefits") to 4 ("strong perceived benefits"): attract new clients (CLIENT), enhance the firm's image (IMAGE), and differentiation from competition (COMP). These items reflect the assumption that each element will lead to value creation and private benefits for the firm. Husted and Allen (2007), who call this variable "appropriability", suggest that one of best ways to extract economic benefits from CSR is product differentiation, through the development of a new product or process. With these three variables, we aim to capture various sources of private benefits, whereas Husted and Allen (2007) used a more general measure linked to "the achievement of social objectives ... necessary to reach financial objectives" (p. 608).

Recall that firms with high scores on these dimensions have strategic CSR, whereas those that score low represent the responsive CSR group.

\section{Principal component and non-hierarchical cluster analyses}

We conducted a principal component analysis $(\mathrm{PCA})^{5}$ on the nine core variables we use to operationalise the CSR dimensions (DOC, SUP, CLIENT, IMAGE, COMP, PLAN AGENDA, STAKE, COM). The measure of sampling adequacy (MSA) confirmed that the variables were good candidates for a PCA (MSA > 0.5). In addition, the Kaiser-Meyer-Olkin (KMO) measure and Bartlett's test of sphericity met common standards (KMO $=0.55, p<$ 0.001). The PCA also identified two factors, in good summary of the theoretical dimensions (49.8\% of total variance). Next we undertook a non-hierarchical cluster analysis, using the scores revealed by the factor analysis. To determine the final number of clusters, we used three common criteria: (1) the statistical accuracy of the classification measured by the ratio of within-cluster and between-clusters variances (Fisher's test), (2) the number of firms per cluster, and (3) the economic significance of the clusters identified. According to these criteria, the version with two clusters of CSR practices is best. ${ }^{6}$ To interpret the two clusters, we calculated the mean of each CSR indicator in each cluster (see Table 1).

\section{Cluster analysis results}

The results may be interpreted by comparing the means in each cluster. In Cluster 1, the 114 firms are intensive CSR adopters, in terms of the number and intensity of the various types

\footnotetext{
${ }^{5}$ We do not present the PCA results here because they are only preparatory stages for our cluster analyses. They are available on request.

${ }^{6}$ For all comparisons of variances, Fisher's test is significant at the 0.000 level and indicates good differentiation among between firms.
} 
of CSR practices they undertake. Engaging in CSR is not only supported by the definition of clear economic objectives at the firm level but requires the adoption of various formalised practices. These practices reflect the firms' ability to incorporate stakeholders' objectives into their business operations. In this sense, CSR means more than the pursuit of common objectives (i.e. firms' and stakeholders' benefits); it is a process in itself that applies to all kinds of decision making, evaluations, and measures. These firms prefer visibility, and they "say what they do". In contrast, the 95 firms in Cluster 2 are poor CSR adopters: They may adopt all kinds of CSR practices, but they score systematically lower than Cluster 1 firms. They have not attained full CSR adoption, lack an asserted economic objective, do not clearly identify their stakeholders, and have not really succeeded in formalising their CSR practices.

\section{Table 1. CSR clusters}

\begin{tabular}{llccccccccc}
\hline \multirow{2}{*}{$\begin{array}{l}\text { Cluster } \\
1\end{array}$} & Mean & $\mathbf{1 . 7 0}$ & $\mathbf{1 . 6 2}$ & $\mathbf{1 . 7 7}$ & $\mathbf{3 . 0 1}$ & $\mathbf{3 . 8 1}$ & $\mathbf{3 . 5 2}$ & $\mathbf{1 . 9 6}$ & $\mathbf{1 . 8 2}$ & $\mathbf{1 . 4 6}$ \\
& $\mathrm{N}$ & 114 & 114 & 113 & 107 & 111 & 110 & 113 & 110 & 114 \\
2 & Mean & 1.31 & 1.27 & 1.42 & 2.54 & 3.47 & 2.97 & 1.51 & 1.51 & 1.13 \\
& $\mathrm{~N}$ & 95 & 95 & 95 & 92 & 94 & 94 & 95 & 91 & 95 \\
F-test & & $* * *$ & $* * *$ & $* * *$ & $* * *$ & $* * *$ & $* * *$ & $* * *$ & $* * *$ & $* * *$ \\
(sig.) & & & & & & & & & & \\
Total & Mean & 1.52 & 1.46 & 1.61 & 2.79 & 3.66 & 3.27 & 1.75 & 1.68 & 1.31 \\
& $\mathrm{~N}$ & 209 & 209 & 208 & 199 & 205 & 204 & 208 & 201 & 209 \\
\hline
\end{tabular}

Notes: We interpret Clusters 1 and 2 according to the variables in the cluster analysis. We computed the mean of each variable for each cluster. The mean appears in bold when it is significantly higher in the considered cluster. For example, strategic CSR profiles (Cluster 1) use significantly more documents describing values and motivations in terms of social issues (DOC) than do Cluster 2 firms.

In line with Burke and Logsdon's (1996) predictions, strategic CSR no longer reflects the presence of a single dimension but instead requires a positive alignment of all strategic dimensions. This result is consistent with Porter and Kramer's (2006) distinction between firms with strategic or responsive CSR. For Cluster 1 firms, expectations of private benefits from CSR are strongly associated with "doing things together". These strategic firms seek to exploit complementarities between inside-out and outside-in linkages, because they take stakeholders explicitly into account as strategic resources. In contrast, Cluster 2 firms offer a responsive vision: They adopt goals and practices but at a low level of intensity. They never reach the "threshold" (here, the mean) that would allow them to go beyond best practices, assuming that their current level of adoption involves good practices. 


\section{The Relationship between CSR profiles and innovation (Step 2)}

To test our main hypothesis, we also must determine whether there is a relationship between innovation and CSR profiles. A descriptive analysis of the proportion of firms with innovative behaviours shows that Cluster 1 firms differ from those in Cluster 2. In Cluster 1, $58 \%$ and $55 \%$ of firms innovate in products and processes, respectively; these proportions are lower in Cluster 2, especially for process innovation: $41 \%$ innovate in products and $23 \%$ in processes. We thus infer that belonging to a specific type of cluster affects the probability that a firm innovates in products and/or processes.

\section{Dependent variables: Two types of technological innovation}

The two dependent variables, product and process innovations, ${ }^{7}$ come from the 2006 Community Innovation Survey, which asked, "During the years 2004 to 2006, did your firm introduce a new or significantly improved product (good or service) or process for making or supplying them?" (INPDGD) and "During the years 2004 to 2006, did your firm introduce one or several of the following processes?" (INSPSPD). Such process innovation might include significant changes in the way that goods or services are produced or provided; the measure differentiated between processes new to the business or new to the industry.

\section{Independent variables: Types of CSR profiles}

To determine the effects of each CSR profile, we introduced the two CSR profiles stemming from the previous classification procedure (CLUSTER_1 and CLUSTER_2), which constitute our main independent variables. We also added the firms' intention to adopt CSR or not, to assess whether firms planning to adopt CSR practices exhibit particular behaviours in terms of the types of innovation. We thus introduced two dummy variables, PLAN_CSR and NO_CSR, ${ }^{8}$ to account for a larger sample.

\section{Control variables}

Finally, we included in the group of regressors the implementation of organizational innovation, to confirm that CSR practices are not simply encompassed in broader organizational practices, which would eliminate any specific effect of CSR. Organizational innovation is a determinant of technological innovation (e.g. Mothe \& Nguyen, 2011).

\footnotetext{
7 In Burke and Logsdon's (1996) model, the dependent variable is value creation. We focus on a more precise aspect of value creation, innovation, in line with Husted and Allen's (2007, p. 597) claim that value creation always and necessarily pertains to innovation.

${ }^{8}$ Including these variables enables us to use all available questionnaire data. These firms constitute part of the overall population that has not implemented CSR practices in the time period under observation.
} 
Accordingly, we measured four organizational practices (OECD, 2005): (1) new business practices for organizing work or procedures; (2) new knowledge management systems; (3) new methods of workplace organization for distributing responsibilities and decision making; and (4) new methods of organizing external relations with other firms or public institutions. These four practices were aggregated into one variable to represent the introduction of (at least) one new or significantly improved organizational practice (INORG).

Following a strategic management perspective, the probability of innovation also depends on a mix of firm-specific characteristics and sector configurations (Cohen, 1995; Teece, 2006), which are common variables in empirical studies (Mairesse \& Mohnen, 2010). Firm capabilities are crucial to its long-term success and innovative performance (Teece \& Pisano, 1994). A strong knowledge base includes R\&D capacity and a well-trained workforce (Cohen \& Levinthal, 1990). We also included data on whether the firm undertakes internal R\&D (RRDIN), in line with McWilliams and Siegel's (2000, 2001) recommendations. Because R\&D expenditures cannot always capture innovation efforts, especially for small firms (Mairesse \& Mohnen, 2010), we also considered the proportion of employees with a higher education degree (NEMPHI) as a proxy for the level of human capital dedicated to innovation.

Another important driver relates to technological opportunities (NPRODPER), that is, the velocity with which products and services become old-fashioned. To control for competitive intensity (Covin et al., 1999; Ozsomer et al., 1997), we included a dummy variable (NMARCONC), equal to 1 when competition in the firm's market is very intense, and 0 otherwise. Appropriability conditions (Teece, 1996) can help generate and maintain rents from leadership in technological activities. Firm size also likely matters in terms of innovation (e.g. Russo \& Fouts, 1997; Wagner, 2010), because large firms have the resources to invest in technological activities and exploit external opportunities, though small ones can also be very innovative, especially in high-technology sectors (Cohen, 1995). We accounted for these effects with a measure of the firm's size ( $\mathrm{T} 1=10-49$ employees, $\mathrm{T} 2=50-249$ employees, T3 $=$ more than 249 employees, according to European classifications). We also added two traditional controls, widely used in studies of CSR and innovation: the sector of activity (e.g. Gallego-Alvarez et al., 2011; Husted \& Allen, 2007; Wagner, 2010) (manufacturing/services, INDUS) and a variable indicating whether the firm belongs to a group (GROUP).

Table 2 contains the definitions of all these variables. Appendices A and B provide summary descriptive statistics for the main variables and their correlations, respectively. 
Table 2. List of variables

\begin{tabular}{|c|c|}
\hline Variables & Description \\
\hline INPDGD & Product innovation: the firm introduces new or significantly improved goods \\
\hline INSPSPD & $\begin{array}{l}\text { Process innovation: the firm introduces new or significantly improved methods of } \\
\text { manufacturing or producing goods or services }\end{array}$ \\
\hline CLUSTER_1 & Firms with strategic CSR profiles \\
\hline CLUSTER_2 & Firms with responsive CSR profiles \\
\hline PLAN_CSR & Plans to adopt CSR \\
\hline NO_CSR & Does not adopt and does not plan to adopt CSR \\
\hline INORG & $\begin{array}{l}\text { Organizational innovation: the firm introduces a new organizational method into its } \\
\text { business practices (including knowledge management), workplace organization, or external } \\
\text { relations }\end{array}$ \\
\hline RRDIN & The firm undertakes internal R\&D activity \\
\hline NEMPHI & Percentage of employees with higher education (post-secondary college and university) \\
\hline NPRODPER & The products and services become rapidly old-fashioned (dummy variable, yes $=1$, no $=0$ ) \\
\hline NMARCONC & The competition in the market is very intense (dummy variable, yes $=1$, no $=0$ ) \\
\hline $\mathrm{T} 1$ & The total number of employees is between 10 and 49 \\
\hline $\mathrm{T} 2$ & The total number of employees is between 50 and 249 \\
\hline $\mathrm{T} 3$ & The total number of employees is more than 249 \\
\hline INDUS & Belongs to the manufacturing sector \\
\hline GROUP & The firm is part of a group \\
\hline
\end{tabular}

Note: Dependent variables are in bold.

\section{Model and estimation}

The basic model for determining whether a set of variables exerts an impact on the decision to innovate is a probit model, which is standard in empirical works that deal with firm behaviour. We could estimate a probit model for each type of innovation (product and process), which would account for the probability that a firm implements each type of innovation. However, the decision to adopt product innovation may relate to the decision to implement process innovation, and firms define their technological strategy for all types of technological aspects. Thus, process and product innovations may not be independent choices, which means that estimating two separate probit models leads to a loss of efficiency and possibly misleading results (Rouvinen, 2002). For this reason, we estimated a bivariate probit model (Table 3) to 
assess the possible relationship between the CSR profiles and the two types of innovation. ${ }^{9}$ The special attention we pay to the possible interaction between product and process innovations differentiates this study from most works, which focus on one or the other (Weiss, 2003). Moreover, this distinction enhances understanding of innovation determinants (Damanpour, 2010). ${ }^{10}$

We use the same set of previously defined regressors. The status of belonging to a CSR cluster describes our two core variables. Table 3 provides the coefficient estimates, through marginal effects on the probability of innovating. We performed a statistical test for $\rho=0$ that indicates the interdependence of the two adoption decisions. The correlation coefficient differs significantly from zero. We assume in our model that the random error terms in the two equations are correlated, so the test confirms the statistical link between the two innovation choices (product and process).

\footnotetext{
${ }^{9}$ To investigate two related decisions by the same individual, a bivariate probit model (or bi-probit) fits the data better than two separated probit models. We test if the bi-probit model is better with widely available software (e.g. Baum, 2006). We further presume that the choice to innovate products correlates to the choice to innovate processes. Thus the covariance between the two terms of errors can differ from zero.

${ }^{10}$ We acknowledge Hoetker's (2007) advice about using probit models in strategic management research.
} 
Table 3. Determinants of innovation behaviours (bivariate probit model)

\begin{tabular}{|c|c|c|}
\hline & \multicolumn{2}{|c|}{ Marginal Effect (standard error) } \\
\hline & INPDGD & INSPSPD \\
\hline \multirow[t]{2}{*}{ CLUSTER_1 } & $0.635531 * * *$ & $0.5472143^{* * *}$ \\
\hline & $(0.143411)$ & $(0.1407221)$ \\
\hline \multirow[t]{2}{*}{ CLUSTER_2 } & -0.053847 & $-0.7756979 * * *$ \\
\hline & $(0.1401149)$ & $(0.1450609)$ \\
\hline \multirow[t]{2}{*}{ PLAN_CSR } & $-0.2778489 * *$ & -0.1881734 \\
\hline & $(0.1231161)$ & $(0.1178849)$ \\
\hline NO_CSR & Reference category & Reference category \\
\hline \multirow[t]{2}{*}{ INORG } & $0.8850447 * * *$ & $0.5828004 * * *$ \\
\hline & $(0.0871822)$ & $(0.0831286)$ \\
\hline \multirow[t]{2}{*}{ RRDIN } & $1.339211 * * *$ & $0.648653^{* * *}$ \\
\hline & $(0.1229137)$ & $(0.1076452)$ \\
\hline \multirow[t]{2}{*}{ NEMPHI } & $0.6959584 * * *$ & $0.8727128 * * *$ \\
\hline & $(0.1383004)$ & $(0.1362914)$ \\
\hline \multirow[t]{2}{*}{ NPRODPER } & $-0.6329258 * * *$ & $-0.1873012 * *$ \\
\hline & $(0.0960763)$ & $(0.0905903)$ \\
\hline \multirow[t]{2}{*}{ NMARCONC } & 0.053673 & $0.3571119 * * *$ \\
\hline & $(0.0880101)$ & $(0.0824224)$ \\
\hline \multirow[t]{2}{*}{$\mathrm{T} 1$} & 0.098066 & 0.10163 \\
\hline & $(0.1069987)$ & $(0.1027805)$ \\
\hline $\mathrm{T} 2$ & Reference category & Reference category \\
\hline \multirow[t]{2}{*}{$\mathrm{T} 3$} & 0.1193759 & $-0.3159759^{*}$ \\
\hline & $(0.2053129)$ & $(0.1838261)$ \\
\hline \multirow[t]{2}{*}{ INDUS } & $0.268331 * *$ & $0.3838273 * * *$ \\
\hline & $(0.105868)$ & $(0.0977941)$ \\
\hline \multirow[t]{2}{*}{ GROUPE } & $0.4554853 * * *$ & $0.7604304 * * *$ \\
\hline & $(0.0883534)$ & $(0.0866091)$ \\
\hline \multirow[t]{2}{*}{ CONST } & $-1.53966 * * *$ & $-1.78133 * * *$ \\
\hline & $(0.1480217)$ & $(0.1486636)$ \\
\hline Sample size & \multicolumn{2}{|c|}{266} \\
\hline -Log-likelihood & \multicolumn{2}{|c|}{-1487.7105} \\
\hline Rho & \multicolumn{2}{|c|}{$0.4728654(0.0455743)$} \\
\hline $\begin{array}{l}\text { Likelihood-ratio test of rho }= \\
0\end{array}$ & \multicolumn{2}{|c|}{$\operatorname{chi} 2(1)=82.6787$ Prob $>\operatorname{chi} 2=0.0000$} \\
\hline
\end{tabular}

\section{Results}

The results indicate succinctly whether belonging to Cluster 1 or to Cluster 2 has an impact on the probability of implementing a specific type of innovation, after controlling for several different factors. In comparison with firms that do not adopt CSR, and as expected, firms with strategic CSR profiles (Cluster 1) are more likely to innovate in both products and processes. 
Hypothesis 1 thus receives support. The results for firms belonging to Cluster 2 (responsive firms) indicate a negative effect on the probability of adopting product or process innovations, though the effect is significant only for process innovation. Hypothesis 2 is thus partially supported. Responsive CSR seems to represent an obstacle, especially to process innovation.

The positive impact of variables that account for the firm's capabilities (RRDIN and NEMPHI) is consistent with strategic management literature. That is, undertaking internal R\&D and hiring many employees with higher education favours firms' product and process innovations. The variable for technological opportunities (NPRODPER) has a significant negative sign, in contrast with prior findings, which might reflect measurement issues and the difficulty of finding a good proxy for this factor, which often interacts with firm innovative performance. The proxy for incentives is significant only for the process innovation equation. Belonging to a market in which competition is very intense enhances the probability of innovating in processes. This result is in line with an industry life-cycle approach: In later stages, when their production volumes have increased, firms try to optimise their production and devote their R\&D investments to process innovation (Klepper, 1996). ${ }^{11}$

The dummy variable for industry is significant for both models; manufacturing firms, not surprisingly, innovate more in products and processes than service firms. Firm size has no overall impact on the probability of innovating. This result is not surprising though, because small firms can benefit from additional resources, especially when they are part of a group.

\section{Discussion, conclusion, and implications for further research}

The objective of this research has been to assess whether firm CSR profiles and practices relate to technological innovation performance, in particular to product and process innovations. Firms in Cluster 1, which take a strategic orientation toward CSR, are more innovative in terms of products and processes, after we control for firm characteristics and key innovation drivers. In line with Baden et al. (2009), we find that firms have no chance of benefiting from CSR in "the absence of intrinsic motivation to engage in CSR" (p. 432). This result offers empirical validation of Burke and Logsdon's (1996) theoretical predictions; it also extends an existing empirical study (Husted \& Allen, 2007) that used only three dimensions. Consistent with Miles and Snow's (1978) model, we confirm that organizational performance depends on the degree of consistency (fit) that managers establish across strategic, organizational, and environmental

\footnotetext{
${ }^{11}$ We bear in mind that existing results are sensitive to the indicator used to measure intra-industry competition. When we retain the concentration ratio, some authors might assert a stronger positive impact of concentration (i.e. less competition) on product innovations than on process innovations (see Cabagnols \& Le Bas, 2002).
} 
elements. All five dimensions (Burke \& Logsdon, 1996) should be aligned to create innovation and its competitive advantage. This internal fit does not imply simply the adoption of good practices, which are both insufficient and possibly poorly aligned with the firm's existing organization. In this case, they could lead to a failure of established strategic routines and declines in performance (Porter \& Siggelkow, 2008).

A lack of alignment also may translate into barriers to innovation, which can produce a vicious circle when the firm cannot link its CSR practices with its strategy (Castiaux, 2009; Galego-Alvarez et al., 2011). This lack of alignment in responsive CSR firms affects their technological innovation negatively, though the negative impact is significant only for process innovation. To explain this result, we note that the best CSR practices adopted by firms thus far have been related mainly to cost reduction objectives. Because they were not integrated into the firm's strategy and organization, they produced a countervailing effect that hindered the firm's capacity to innovate in processes.

These results offer several implications for theory and research on CSR and innovation. In particular, our results offer empirical confirmation of previous theoretical assumptions about the link between CSR practices and innovation, though they address this link much more carefully. This finding also confirms an OECD (2009) report about the "new nature of innovation": Social concerns increasingly drive innovation. Moreover, our results suggest that a firm with strategic CSR can sustain a competitive advantage and ensure better, longer-lasting economic performance than a firm with responsive CSR. From an evolutionary perspective, their likelihood of survival is higher. The social technology supported through strategic CSR also offers more chances for growth, whereas responsive CSR firms engage in behaviours more closely related to lower economic performance, so their probability of failure in the medium term increases. Institutions put forth (responsive CSR) thus might bar innovation. To put it simply (at least as a prediction of our study), responsive CSR seems unsustainable and not viable. Strategic CSR better fits the socio-economic context and enables both the improvement of stakeholder revenues and enhanced life quality with constraints only due to stockholders' demands.

For CSR and innovation managers, we reveal that to foster product and process innovations, firms should adopt formalised CSR practices and establish procedures and tools aligned with their corporate strategy. When they have strategic CSR (Porter \& Kramer, 2006), firms clearly identify their stakeholders and focus on external visibility, such that they "say what they do" in formal documents that clearly describe their CSR practices. Furthermore, managers might employ our results to guide their use of CSR practices to enhance 
technological innovation or their exploitation of technological innovation to introduce CSR practices. Strategic orientation is key in both areas. In turn, this finding indicates major implications for public policy support for innovation and/or CSR firm engagement - a link that requires further studies to detail the relevant complementarities (Mohnen \& Roller, 2005). A package of policies may be needed to help firms engage in either CSR or innovation processes.

Our study is not exempt from limitations. A primary one relates to the specific economic structure of Luxembourg, where service firms have a very important place. Additional research should replicate this study in countries where industry and service sectors play equally important roles. Longitudinal data would be useful to assess whether strategic CSR behaviour is linked to persistent technological innovations. Further research also could take into account the likely complementarities between the different types of innovation; Polder et al. (2010) already have shown that product and process innovations have positive effects on productivity when combined with organizational innovation. It thus seems relevant to test for complementarity through tri-variate probit models that account for the combined effects of product, process, and organizational innovations. Other types of non-technological innovations (e.g. marketing, business models) could also be considered. More generally, our analysis might be extended with additional research on the complex relationship among CSR, innovation, and value creation that examines further the differentiated impacts on types of innovation. 


\section{References}

Aragón-Correa, J., \& Sharma, S. (2003). A contingent resource-based view of proactive corporate environmental strategy. Academy of Management Review, 28(1), 71-88.

Baden, D. A., Harwood, I. A., \& Woodward, D. G. (2009). The effect of buyer pressure on suppliers in SMEs to demonstrate CSR practices: An added incentive or counter productive? European Management Journal, 27(6), 429-441.

Banerjee, S. B. (2007). Corporate social responsibility: The good, the bad and the ugly. Cheltenham: Edward Elgar.

Baum, C. F. (2006). An introduction to modern econometrics using Stata. College Station, T.X.: Stata Press.

Bocquet, R. (2011). Product and process innovations in subcontracting: Empirical evidence from the "Sillon Alpin". Industry and Innovation, 18(7), 649-668.

Burke, L., \& Logsdon, M. (1996). How corporate social responsibility pays off. Long Range Planning, 29(4), 495-502.

Buysse, K., \& Verbeke, A. (2003). Proactive environmental strategies: A stakeholder management perspective. Strategic Management Journal, 24(5), 453-470.

Cabagnols, A., \& Le Bas, C. (2002). The determinants of the type of innovative behaviour at the firm level. In A. Kleinknecht, \& P. Mohnen (Eds.), Innovation and firm performance: Econometric explorations of survey data. (pp. 112-149). London: Palgrave Macmillan.

Carroll, A. (1999). Corporate social responsibility: evolution of a definitional construct. Business and Society, 38, 268-295.

Castiaux, A. (2009). Responsabilité d'entreprise et innovation: Entre exploration et exploitation. Reflets et perspectives de la vie économique, XLVIII, 37-49.

Chassagnon, V. (2011). The law and economics of the modern firm: A new governance structure of power relationships. Revue d'Economie Industrielle, 134, 25-50.

Cohen, W. (1995). Empirical studies of innovative activity. In P. Stoneman (Ed.), Handbook of the economic of innovation and technological change (pp. 182-264). Oxford: Blackwell.

Cohen, W. M., \& Levinthal, D. A. (1990). Absorptive capacity: A new perspective of learning and innovation. Administrative Science Quarterly, 35(1990), 128-152.

Commission of the European Communities (2001). Promoting a European framework for corporate social responsibility, Green paper, COM 366 final, Brussels.

Covin, J. G., Slevin, D. P., \& Heelewy, M. B. (1999). Pioneers and followers: competitive tactics, environment and firm growth. Journal of Business Venturing, 15, 175-210. 
Damanpour, F. (2010). An integration of research findings of effects of firm size and market competition on product and process innovations. British Journal of Management, 21(4), 996-1010.

Devinney, T. M. (2009). Is the socially responsible corporation a myth? The good, bad and ugly of corporate social responsibility. Academy of Management Perspectives, (May), 4456.

Dibrell, C., Craig, J., \& Hansen, E. (2011). Natural environment, market orientation, and firm innovativeness: an organizational life cycle perspective. Journal of Small Business Management, 49(3), 467-489.

European Commission (2011). Towards a greater understanding of the changing role of business in society. Luxembourg, Belgium: General Directorate for Research and Innovation, Socio-economic Sciences and Humanities.

Fagerberg, J. (2005). Innovation, a guide to the literature. In J. Fagerberg, D.C. Mowery, \& R.E. Nelson (Eds.), The Oxford handbook of innovation (pp. 1-28). New York: Oxford University Press.

Fernando, M. (2010). Corporate social responsibility in the wake of the Asian tsunami: Effect of time on the genuineness of CSR initiatives. European Management Journal, 28(1), $68-79$.

Fiss, T. C., \& Zajac, E. J. (2006). The symbolic management of strategic change: Sensegiving framing and decoupling. Academy of Management Journal, 49(6), 1173-1193.

Gallego-Alvarez, I., Prado-Lorenzo J. M., \& Garcia-Sanchez, I-M. (2011). Corporate social responsibility and innovation: A resource-based theory. Management Decision, 49(10), 1709-1727.

Hart, S. L. (1995). A natural-resource-based view of the firm. Academy of Management Review, 20(4), 986-1014.

Harwood, I., Humby, S., \& Harwood, A. (2011). On the resilience of corporate social responsibility. European Management Journal, 29(4), 283-290.

Hoetker, G. (2007). The use of logit and probit models in strategic management research: Critical issues. Strategic Management Journal, 28, 331-343.

Husted, B. W., \& Allen, D. B. (2007). Strategic corporate social responsibility and value creation among large companies. Long Range Planning, 40, 594-610.

Jaffe, A. B., \& Palmer, J. (1997). Environmental regulation and innovation: A panel study. Review of Economics \& Statistics, 79(4), 610-619. 
Jenkins, H. (2006). Small business champions for corporate social responsibility. Journal of Business Ethics, 67, 241-256.

Klepper, S. (1996). Entry, exit, growth, and innovation over the product life cycle. American Economic Review, 86(3), 562-83.

Knox, S., \& Maklan, S. (2004). Corporate social responsibility: Moving beyond investment towards measuring outcomes. European Management Journal, 22(5), 508-516.

Lockett, A., Moon, J., \& Wayne, V. (2006). Corporate social responsibility in management research: focus, nature, salience and sources of influence. Journal of Management Studies, 43, 115-36.

Mairesse, J., \& Mohnen, P. (2010). Using innovation surveys for econometric analysis. Working Paper 15857. Cambridge, MA: National Bureau of Economic Research.

McWilliams, A., \& Siegel, D. S. (2000). Corporate social responsibility and financial performance: Correlation or misspecification? Strategic Management Journal, 21(5), 603-609.

McWilliams, A., \& Siegel, D. S. (2001). Corporate social responsibility: A theory of the firm perspective. Academy of Management Review, 26(1), 117-127.

Miles, R. E., \& Snow, C. C. (1978). Organizational strategy, structure and process. New York: McGraw-Hill.

Mohnen, P., \& Roller, L. (2005). Complementarities in innovation policy. European Economic Review, 49(6), 1431-1450.

Moore, G., Slack, R., \& Gibbon, J. (2009). Criteria for responsible business practice in SMEs: An exploratory case of U.K. fair trade organisations. Journal of Business Ethics, 89, 173188.

Mothe, C., \& Nguyen, U. (2012). Non-technological and technological innovations: Do services differ from manufacturing? An empirical analysis of Luxembourg firms. International Journal of Technology Management, 57(4), 227-244.

Muller, A. (2006). Global versus local CSR strategies. European Management Journal, 24(2/3), 189-198.

Murillo, D., \& Lozano, J. M. (2006). SMEs and CSR: An approach to CSR in their own words. Journal of Business Ethics, 67, 227-240.

Nidumolu, R., Prahalad, C. K., \& Rangaswami, M. R. (2009). Why sustainability is now the key driver of innovation. Harvard Business Review, (September), 56-64.

OECD (2005). The measurement of scientific and technological activities: Proposed guidelines for collecting and interpreting technological innovation data. Oslo Manual. 
OECD (2009). The new nature of innovation (http://www.newnatureofinnovation.org/).

Ozsomer, A., Calantone, R., \& Benedetto, A. D. (1997). What makes firms more innovative? A look at organizational and environmental factors. Journal of Business and Industrial Marketing, 12, 400-416

Perrini, F. (2005). Building a European portrait of corporate social responsibility reporting. European Management Journal, 23(6), 611-627.

Polder, M., Van Leeuwen, G., Mohnen, P., \& Raymond, W. (2010). Product, process and organizational innovation: Drivers, complementarity and productivity effects. UNUMERIT Working Paper Series 035, Maastricht Economic and Social Research and Training Centre on Innovation and Technology.

Porter, M. E., \& Kramer, M. R. (2006). Strategy and society. Harvard Business Review, December, 77-92.

Porter, M. E., \& Kramer, M. R. (2011). Creating shared value. Harvard Business Review, $89(1 / 2), 62-77$.

Porter, M., \& Siggelkow, N. (2008). Contextuality within activity systems and sustainability of competitive advantage. Academy of Management Perspectives, 22(2), 34-56.

Porter, M. E., \& van der Linde, C. (1995). Toward a new conception of the environmentcompetitiveness relationship. Journal of Economic Perspectives, 9(4), 97-118.

Rehfeld, K., Rennings, K., \& Ziegler, A. (2007). Integrated product policy and environmental product innovations: An empirical analysis. Ecological Economics, 61(1), 91-100.

Rennings, K., \& Rammer, C. (2011). The impact of regulation-driven environmental innovation on innovation success and firm performance. Industry \& Innovation, 18(3), 255-283.

Rouvinen, P. (2002). Characteristics of product and process innovators: Some evidence from the Finnish innovation survey. Applied Economics Letters, 9, 575-580.

Russo, M., \& Fouts, P. (1997). A resource-based perspective on corporate environmental performance and profitability. Academy of Management Journal, 40, 534-59.

Sharma, S., \& Vredenburg, H. (1998). Proactive corporate environmental strategy and the development of competitively valuable organizational capabilities. Strategic Management Journal, 19(8), 729-753.

Surroca, J., Tribó, J. A., \& Waddock, S. (2010). Corporate responsibility and financial performance: The role of intangible resources. Strategic Management Journal, 31(5), 463-490. 
Teece, D. J. (1996). Firm organization, industrial structure, and technological innovation. Journal of Economic Behavior \& Organization, 31(2), 193-224.

Teece, D. J. (2006). Reflections on "Profiting from Innovation", Research Policy, 35(8), 11311146.

Teece, D. J., \& Pisano, G. (1994). The dynamic capabilities of firms: An introduction. Industrial and Corporate Change, 3, 537-556.

Tencati, A., Perrini, F., \& Pogutz, S. (2004). New tools to foster corporate socially responsible behavior. Journal of Business Ethics, 53, 173-190.

Wagner, M. (2010), Corporate social performance and innovation with high social benefits: a quantitative analysis. Journal of Business Ethics, 94, 581-594.

Wartick, S. L., \& Cochran, P. L. (1985). The evolution of the corporate social performance model. Academy of Management Review, 10(4), 758-769.

Weber, M. (2008). The business case for corporate social responsibility: A company-level measurement approach for CSR. European Management Journal, 26(4), 247-261.

Weiss, P. (2003). Adoption of product and process innovations in differentiated markets: The impact of competition. Review of Industrial Organization, 23, 301-314.

Wilson, I. (1975). What one company is doing about today's demands on business. In: George A. Steiner (ed.), Changing business-society interrelationships. Los Angeles: Graduate School of Management, UCLA. 
Appendix A. Statistical variable descriptions

\begin{tabular}{lcc}
\hline Variables & Mean & Standard Error \\
INPDGD & 0.36157943 & 1.11654759 \\
INSPSPD & 0.3377076 & 1.09904948 \\
CLUSTER_1 & 0.09591498 & 0.68433666 \\
CLUSTER_2 & 0.12959299 & 0.78050177 \\
PLAN_CSR & 0.13267664 & 0.78833299 \\
NO_CSR & 0.64181539 & 1.11424442 \\
INORG & 0.53438103 & 1.1592118 \\
RRDIN & 0.15899505 & 0.84979276 \\
NPRODPER & 0.33192173 & 1.09434299 \\
NEMPHI & 0.29231013 & 0.71749629 \\
NMARCONC & 0.60810426 & 1.13447842 \\
T1 & 0.72616142 & 1.03630083 \\
T2 & 0.22064017 & 0.96368088 \\
T3 & 0.05319841 & 0.52155579 \\
INDUS & 0.21843196 & 0.96020382 \\
GROUP & 0.46705088 & 1.15943636 \\
\hline
\end{tabular}

Notes: For all variables, the mean value is 0 , and the max value is 1 . 


\begin{tabular}{|c|c|c|c|c|c|c|}
\hline 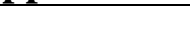 & INPCS & INPDT & CLUSTER_1 & CLUSTER_2 & PLAN_CSR & NO_CSR \\
\hline INPCS & 1 & & & & & \\
\hline \multirow[t]{2}{*}{ INPDT } & 0.45458 & 1 & & & & \\
\hline & $<.0001$ & & & & & \\
\hline \multirow[t]{2}{*}{ CLUSTER_1 } & 0.07421 & 0.07695 & 1 & & & \\
\hline & 0.2277 & 0.2109 & & & & \\
\hline \multirow[t]{2}{*}{ CLUSTER_2 } & 0.09615 & 0.2458 & -0.14217 & 1 & & \\
\hline & 0.1177 & $<.0001$ & 0.0204 & & & \\
\hline \multirow[t]{2}{*}{ PLAN_CSR } & 0.00554 & -0.03371 & -0.14217 & -0.17181 & 1 & \\
\hline & 0.9284 & 0.5842 & 0.0204 & 0.005 & & \\
\hline \multirow[t]{2}{*}{ NO_CSR } & -0.11999 & -0.20148 & -0.4214 & -0.50924 & -0.50924 & 1 \\
\hline & 0.0506 & 0.001 & $<.0001$ & $<.0001$ & $<.0001$ & \\
\hline \multirow[t]{2}{*}{ INORG } & 0.25254 & 0.36619 & -0.07158 & 0.16864 & 0.03992 & -0.10582 \\
\hline & $<.0001$ & $<.0001$ & 0.2447 & 0.0058 & 0.5168 & 0.085 \\
\hline \multirow[t]{2}{*}{ RRDIN } & 0.3708 & 0.55254 & 0.05495 & 0.15123 & -0.06912 & -0.09377 \\
\hline & $<.0001$ & $<.0001$ & 0.372 & 0.0135 & 0.2613 & 0.1272 \\
\hline \multirow[t]{2}{*}{ NPRODPER } & -0.01749 & -0.12032 & -0.03341 & 0.03595 & 0.14611 & -0.11059 \\
\hline & 0.7765 & 0.05 & 0.5874 & 0.5594 & 0.0171 & 0.0717 \\
\hline \multirow[t]{2}{*}{ NEMPHI } & 0.0599 & 0.29986 & 0.10867 & 0.07453 & 0.04456 & -0.15415 \\
\hline & 0.3304 & $<.0001$ & 0.0769 & 0.2257 & 0.4693 & 0.0118 \\
\hline \multirow[t]{2}{*}{ NMARCONC } & 0.13067 & 0.0846 & 0.05654 & 0.03659 & 0.03659 & -0.08831 \\
\hline & 0.0331 & 0.1689 & 0.3584 & 0.5525 & 0.5525 & 0.1509 \\
\hline \multirow[t]{2}{*}{ T1 } & -0.10117 & -0.19463 & -0.13119 & -0.17459 & 0.01811 & 0.19529 \\
\hline & 0.0997 & 0.0014 & 0.0325 & 0.0043 & 0.7687 & 0.0014 \\
\hline \multirow[t]{2}{*}{$\mathbf{T} 2$} & 0.03815 & 0.04613 & 0.04609 & -0.05517 & 0.00996 & 0.00377 \\
\hline & 0.5356 & 0.4537 & 0.4541 & 0.3701 & 0.8716 & 0.9512 \\
\hline \multirow[t]{2}{*}{$\mathbf{T 3}$} & 0.08568 & 0.20108 & 0.11559 & 0.30878 & -0.03766 & -0.26834 \\
\hline & 0.1635 & 0.001 & 0.0597 & $<.0001$ & 0.5408 & $<.0001$ \\
\hline \multirow[t]{2}{*}{ INDUS } & 0.15205 & 0.11431 & -0.09402 & 0.05551 & -0.07364 & 0.07203 \\
\hline & 0.013 & 0.0626 & 0.1261 & 0.3671 & 0.2313 & 0.2417 \\
\hline \multirow[t]{2}{*}{ GROUP } & 0.13099 & 0.24452 & -0.07608 & 0.24134 & 0.02877 & -0.14746 \\
\hline & 0.0327 & $<.0001$ & 0.2162 & $<.0001$ & 0.6404 & 0.0161 \\
\hline
\end{tabular}




\begin{tabular}{|c|c|c|c|c|c|}
\hline & INORG & RRDIN & NPRODPER & NEMPHI & NMARCONC \\
\hline INORG & 1 & & & & \\
\hline \multirow[t]{2}{*}{ RRDIN } & 0.2966 & 1 & & & \\
\hline & $<.0001$ & & & & \\
\hline \multirow[t]{2}{*}{ NPRODPER } & -0.0414 & -0.01228 & 1 & & \\
\hline & 0.5014 & 0.8419 & & & \\
\hline \multirow[t]{2}{*}{ NEMPHI } & 0.25655 & 0.20666 & -0.16895 & 1 & \\
\hline & $<.0001$ & 0.0007 & 0.0057 & & \\
\hline \multirow[t]{2}{*}{ NMARCONC } & 0.16622 & 0.06978 & -0.0092 & -0.01774 & 1 \\
\hline & 0.0066 & 0.2567 & 0.8813 & 0.7733 & \\
\hline \multirow[t]{2}{*}{$\mathbf{T 1}$} & -0.17455 & -0.26991 & -0.00165 & -0.10705 & 0.00099 \\
\hline & 0.0043 & $<.0001$ & 0.9786 & 0.0814 & 0.9872 \\
\hline \multirow[t]{2}{*}{$\mathbf{T} 2$} & 0.05932 & 0.05839 & -0.00084 & 0.05006 & -0.02131 \\
\hline & 0.3352 & 0.3428 & 0.9891 & 0.4161 & 0.7294 \\
\hline \multirow[t]{2}{*}{$\mathbf{T 3}$} & 0.15646 & 0.28628 & 0.00334 & 0.07776 & 0.02701 \\
\hline & 0.0106 & $<.0001$ & 0.9567 & 0.2062 & 0.661 \\
\hline \multirow[t]{2}{*}{ INDUS } & -0.03964 & 0.24188 & 0.09056 & -0.3099 & 0.00082 \\
\hline & 0.5198 & $<.0001$ & 0.1408 & $<.0001$ & 0.9894 \\
\hline \multirow[t]{3}{*}{ GROUP } & 0.1811 & 0.26412 & -0.03692 & 0.13923 & 0.05984 \\
\hline & 0.003 & $<.0001$ & 0.5489 & 0.0231 & 0.331 \\
\hline & T1 & T2 & T3 & INDUS & GROUP \\
\hline T1 & 1 & & & & \\
\hline \multirow[t]{2}{*}{$\mathbf{T} 2$} & -0.72126 & 1 & & & \\
\hline & $<.0001$ & & & & \\
\hline \multirow[t]{2}{*}{ T3 } & -0.38912 & -0.35742 & 1 & & \\
\hline & $<.0001$ & $<.0001$ & & & \\
\hline \multirow[t]{2}{*}{ INDUS } & -0.0654 & 0.02128 & 0.05987 & 1 & \\
\hline & 0.2879 & 0.7297 & 0.3307 & & \\
\hline \multirow[t]{2}{*}{ GROUP } & -0.42323 & 0.25496 & 0.23158 & 0.06973 & 1 \\
\hline & $<.0001$ & $<.0001$ & 0.0001 & 0.2571 & \\
\hline
\end{tabular}

Notes: Pearson correlation coefficients, Prob > |r| under H0: Rho $=0$. 